\title{
BMJ Open Cost-effectiveness analysis of a physician deployment program to improve access to healthcare in rural and underserved areas in the Philippines
}

\author{
Anton L.V. Avanceña (i) , ${ }^{1}$ Kim Patrick S Tejano, ${ }^{2}$ David W. Hutton (i) ${ }^{1,3}$
}

To cite: Avanceña AL.V, Tejano KPS, Hutton DW. Costeffectiveness analysis of a physician deployment program to improve access to healthcare in rural and underserved areas in the Philippines. BMJ Open 2019:9:e033455. doi:10.1136/ bmjopen-2019-033455

- Prepublication history and additional material for this paper are available online. To view these files, please visit the journal online (http://dx.doi. org/10.1136/bmjopen-2019033455).

Received 06 August 2019 Revised 01 December 2019 Accepted 05 December 2019

Check for updates

(c) Author(s) (or their employer(s)) 2019. Re-use permitted under CC BY-NC. No commercial re-use. See rights and permissions. Published by BMJ.

${ }^{1}$ Department of Health Management and Policy, University of Michigan School of Public Health, Ann Arbor, Michigan, United States ${ }^{2}$ Health Policy Development and Planning Bureau, Philippines Department of Health, Manila, Philippines

${ }^{3}$ Department of Industrial and Operations Engineering, University of Michigan College of Engineering, Ann Arbor, Ml, United States

Correspondence to Mr Anton L.V. Avanceña; antonlv@umich.edu

\section{ABSTRACT}

Objectives The objective of this study is to explore the cost-effectiveness of Doctor to the Barrios (DTTB), a physician deployment program in the Philippines. Design Cost-effectiveness analysis using decision tree models with a lifetime time horizon and probabilistic sensitivity analysis.

Setting Societal and healthcare perspectives.

Population Hypothetical cohort of children under 5 years in two provinces (Aklan and Nueva Ecija) and in a representative rural municipality.

\section{Participants None.}

Interventions DTTB's impact on paediatric pneumonia and diarrhoea outcomes compared with a scenario without DTTB.

Main outcome measures Costs, effectiveness (in terms of lives saved and quality-adjusted life years (QALYs) gained) and incremental cost-effectiveness ratio (ICER).

Results DTTB is cost-effective in the two provinces that were included in the study from societal and healthcare perspectives. Looking at a representative rural municipality, base case analysis and probabilistic sensitivity analyses suggest that DTTB has an ICER of 27192 per QALY gained from a societal perspective. From a healthcare perspective, the base case ICER of DTTB is Philippine pesos (PHP) 71839 per QALY gained and PHP 2064167 per life saved, and 10000 Monte Carlo simulations produced similar average estimates. The cost per QALY of DTTB from a healthcare perspective is lower than the WHO recommended willingness-to-pay threshold of $100 \%$ of the country's per-capita gross domestic product.

Conclusions DTTB can be a cost-effective intervention, but its value varies by setting and the conditions of the municipality where it is implemented. By focusing on a narrow set of paediatric outcomes, this study has likely underestimated the health benefits of DTTB. Additional research is needed to understand the full extent of DTTB's impact on the health of communities in rural and remote areas. Future cost-effectiveness analysis should empirically estimate various parameters and include other health conditions in addition to pneumonia and diarrhoea in children.
Strengths and limitations of this study

- This study is the first to explore the cost-effectiveness of a deployment programme for clinicians in the Philippines intended to improve healthcare access in rural and underserved areas.

- This study provides evidence that expansion of deployment programme may be a cost-effective policy in some situations.

Robust sensitivity analyses were performed to capture uncertainty in the results, determine key drivers of uncertainty and to illustrate the value of further research.

- Societal and healthcare perspectives were considered in the analyses in order to support different policymaking considerations.

- Only a narrow set of health outcomes for paediatric populations were considered in this study, which likely underestimates the true benefits of physician deployment in rural and underserved communities.

\section{INTRODUCTION}

Like many low-income and middle-income countries, the Philippines suffers not only from a shortage of human resources for health (HRH) but also from their maldistribution. Though $56 \%$ of Filipinos reside in rural areas, ${ }^{1}$ about $60 \%-70 \%$ of $\mathrm{HRH}$ in the Philippines are concentrated in urban centres. ${ }^{23}$ For example, the physician density in the National Capital Region is 17.5 times higher than in the Autonomous Region in Muslim Mindanao, the poorest and most rural region in southern Philippines. ${ }^{2}$ To address this issue, the newly passed Universal Health Care Act, ${ }^{45}$ signed by President Rodrigo Duterte in February 2019, proposes to establish a National Health Workforce Support System, which scales up existing HRH deployment programme in the public sector such as Doctor to the Barrios (DTTB). 
Started in 1993, DTTB is an incentive-based physician deployment programme of the Philippines Department of Health (DoH) that recruits medical doctors (primarily general practitioners though other primary care physicians are also deployed) to work in rural, geographically isolated and underserved municipalities for 2 years. DTTB physicians are offered a higher-than-average salary, living and transportation allowances, hazard pay and professional development trainings, including the opportunity to earn a certificate or Master of Public Health degree. ${ }^{6}$ DTTB has deployed 35 groups of physicians so far, and in 2019, 215 physicians were serving as municipal health officers (MHOs) or rural health physicians (RHPs) in rural health units (RHUs), which are the lowest-level health facilities in the Philippines where various preventive and primary care services are provided. ${ }^{67}$

Municipalities that do not participate in DTTB fill $\mathrm{MHO}$ and RHP vacancies through standard hiring procedures determined by the Local Government Code. Hiring through this process can take long because many physicians prefer to work in large cities; in addition, recruited physicians are paid the average government wage for doctors working in the public sector, which is lower than DTTB and has been associated with physician dissatisfaction and high turnover rates. ${ }^{7}$

Because physicians and other HRH are an essential input to any healthcare system, increasing physician density in rural, isolated and underserved areas can improve population health by improving access to basic and high-quality healthcare services. ${ }^{8-10}$ Several studies have reported that HRH density is positively associated with use of preventive healthcare services and negatively associated with disease complications and death from cancer, diabetes, AIDS and other conditions. ${ }^{11-18}$ HRH density has also been associated with reductions in under 5 years mortality in various settings. ${ }^{19}{ }^{20}$ In addition to improving health outcomes, physician deployment programmes like DTTB can promote health equity and advance the Philippines's goal to achieve universal healthcare.

The Philippine government is poised to allocate significant resources on scaling up various deployment programmes including DTTB; however, the costeffectiveness of these programmes has not been explored before. In this study, we aimed to estimate the costeffectiveness of DTTB in reducing pneumonia-related and diarrhoea-related mortality among children under 5 years compared with its alternative (ie, standard hiring and recruitment procedures employed by local governments). The target audiences for this study are national and local government policymakers in the Philippines and in other countries exploring the utility of $\mathrm{HRH}$ deployment programmes.

After careful discussions with DoH officials, pneumonia and diarrhoea were chosen because these two conditions are in the top five causes of death among young children. ${ }^{21}{ }^{22}$ In 2017, an estimated 3760 children under 5 years died of diarrhoea, which is more than $50 \%$ of all diarrhoeal deaths in the country that year. ${ }^{23}$ Of the estimated 2.6 million cases of pneumonia among children under 5 years in 2017, about 12400 resulted in deaths. ${ }^{23}$ Pneumonia and diarrhoea were also selected as outcomes because DTTB physicians (as MHOs and RHPs) are uniquely positioned to treat and address these diseases; for example, physicians, unlike other healthcare workers, are trained to determine when and what types of antibiotics are needed and have regulatory authority to dispense these drugs to patients.

Pneumonia and diarrhoea are caused by several pathogens including bacteria and viruses. In the Philippines, pneumonia is commonly caused by Streptococcus pneumoniae, Haemophilus influenzae type b (Hib), respiratory syncytial virus and influenza virus ${ }^{24} 25$; for diarrhoeal disease, rotaviruses, noroviruses and bacteria such as Escherichia coli, Campylobacter spp and others are the main etiologic agents. ${ }^{26}$ International and local treatment guidelines specify the administration of antibiotic therapy for bacterial pneumonia and diarrhoea, while antiviral medications are indicated for severe viral pneumonia. ${ }^{27}$ Diarrhoea caused by viruses (referred to as viral gastroenteritis) are mainly treated through symptomatic support such as through oral rehydration therapy. ${ }^{28} 29$ Vaccines are available for selected pneumonia and diarrhoea pathogens (eg, S. pneumoniae, Hib, influenza, rotavirus, cholera and so on) and several have been rolled out in the Philippines. ${ }^{26} 3031$ However, uptake throughout the country has been variable due to several cost and accessibility barriers. ${ }^{32-34}$

\section{MATERIALS AND METHODS}

This cost-effectiveness analysis (CEA) follows the guidance proposed by the 2nd Panel on Cost-effectiveness in Health and Medicine (2nd Panel), ${ }^{35}$ as well as the Consolidated Health Economic Evaluation Reporting Standards reporting guidelines. ${ }^{36}$ We used decision tree models that simulate a hypothetical cohort of children under 5 years to estimate the impact of DTTB on pneumonia-related and diarrhoea-related outcomes and costs.

We conducted two sets of analyses in this study. One set uses, where available, province-specific inputs to estimate the base case cost-effectiveness of DTTB in two conveniently sampled provinces (Aklan and Nueva Ecija). The other set of analyses models a representative rural municipality in the Philippines, where DTTB physicians are typically deployed. The aim of simulating a representative municipality is to determine the conditions in which DTTB is cost-effective outside of the two provinces sampled.

We considered societal and healthcare perspectives in the analysis. In the societal perspective, which is the recommended perspective for economic evaluations in healthcare, ${ }^{35}$ all costs and benefits are valued and included, regardless of the payer or beneficiary. In the healthcare perspective, only medical care and intervention costs borne by payers and patients are included. 
Table 1 Impact inventory*

\begin{tabular}{|c|c|c|c|c|}
\hline Sector & Type of impact & $\begin{array}{l}\text { Healthcare } \\
\text { perspective }\end{array}$ & $\begin{array}{l}\text { Societal } \\
\text { perspective }\end{array}$ & $\begin{array}{l}\text { Notes on sources of } \\
\text { evidence }\end{array}$ \\
\hline \multicolumn{5}{|l|}{ Formal healthcare sector } \\
\hline \multirow{5}{*}{ Health } & $\begin{array}{l}\text { Health-related quality-of-life } \\
\text { effects }\end{array}$ & $x$ & $x$ & \\
\hline & $\begin{array}{l}\text { Other health effects (eg, caregiver } \\
\text { health-related quality of life) }\end{array}$ & & & Excluded due to lack of data \\
\hline & $\begin{array}{l}\text { Medical costs paid for by third- } \\
\text { party payers }\end{array}$ & $\mathrm{X}$ & $x$ & See table 2 \\
\hline & $\begin{array}{l}\text { Medical costs paid for by patients } \\
\text { out-of-pocket }\end{array}$ & $\mathrm{x}$ & $x$ & See table 2 \\
\hline & Future-related medical costs & & & $\begin{array}{l}\text { We assumed no related costs } \\
\text { after age } 3\end{array}$ \\
\hline \multirow[t]{3}{*}{ Health } & Patient costs & & & $\begin{array}{l}\text { Not applicable due to patients' } \\
\text { age }\end{array}$ \\
\hline & Unpaid caregiver time costs & $\mathrm{X}$ & $\mathrm{X}$ & See table 2 \\
\hline & Transportation costs & & $x$ & See table 2 \\
\hline \multicolumn{5}{|l|}{ Non-healthcare sectors } \\
\hline \multirow[t]{3}{*}{ Productivity } & Formal labour market earnings lost & & $x$ & See table 2 \\
\hline & $\begin{array}{l}\text { Cost of unpaid lost productivity } \\
\text { due to illness }\end{array}$ & & & Excluded due to lack of data \\
\hline & $\begin{array}{l}\text { Cost of uncompensated } \\
\text { household production }\end{array}$ & & & Excluded due to lack of data \\
\hline Housing & None & & & \\
\hline Environment & None & & & \\
\hline
\end{tabular}

*The Impact inventory allows analysts to consider all the consequences of a health intervention from various perspectives. Marks $(X)$ indicate whether a particular impact was included in the perspective listed at the top of the column.

We generated an impact inventory (table 1) that lists all the health and non-health costs and effects that were included in each perspective..$^{35}$

We examine pneumonia and diarrhoea outcomes during the course of a year and simulate the lifetime outcomes following that illness. We projected benefits in terms of lives saved and quality-adjusted life years (QALYs) gained over the lifetime of a hypothetical cohort. We discounted future benefits to present value using a $3 \%$ rate in the base case analysis.

\section{Patient and public involvement}

This study was conducted with the support of various stakeholders in the public sector. DoH staff and researchers informed the design of the study and assisted in developing the decision analytic model used in the analysis. DTTB physicians and allied healthcare providers were interviewed to gather expert opinion on select treatmentrelated inputs in the model.

\section{Decision tree model}

We developed two decision tree models that separately estimate the high-level costs and effectiveness of implementing DTTB compared with a scenario without DTTB on pneumonia and diarrhoea outcomes (figure 1). Structurally, the models for scenarios with and without DTTB are exactly alike; the most significant difference is in the likelihood of physicians being present at the RHU, which, 

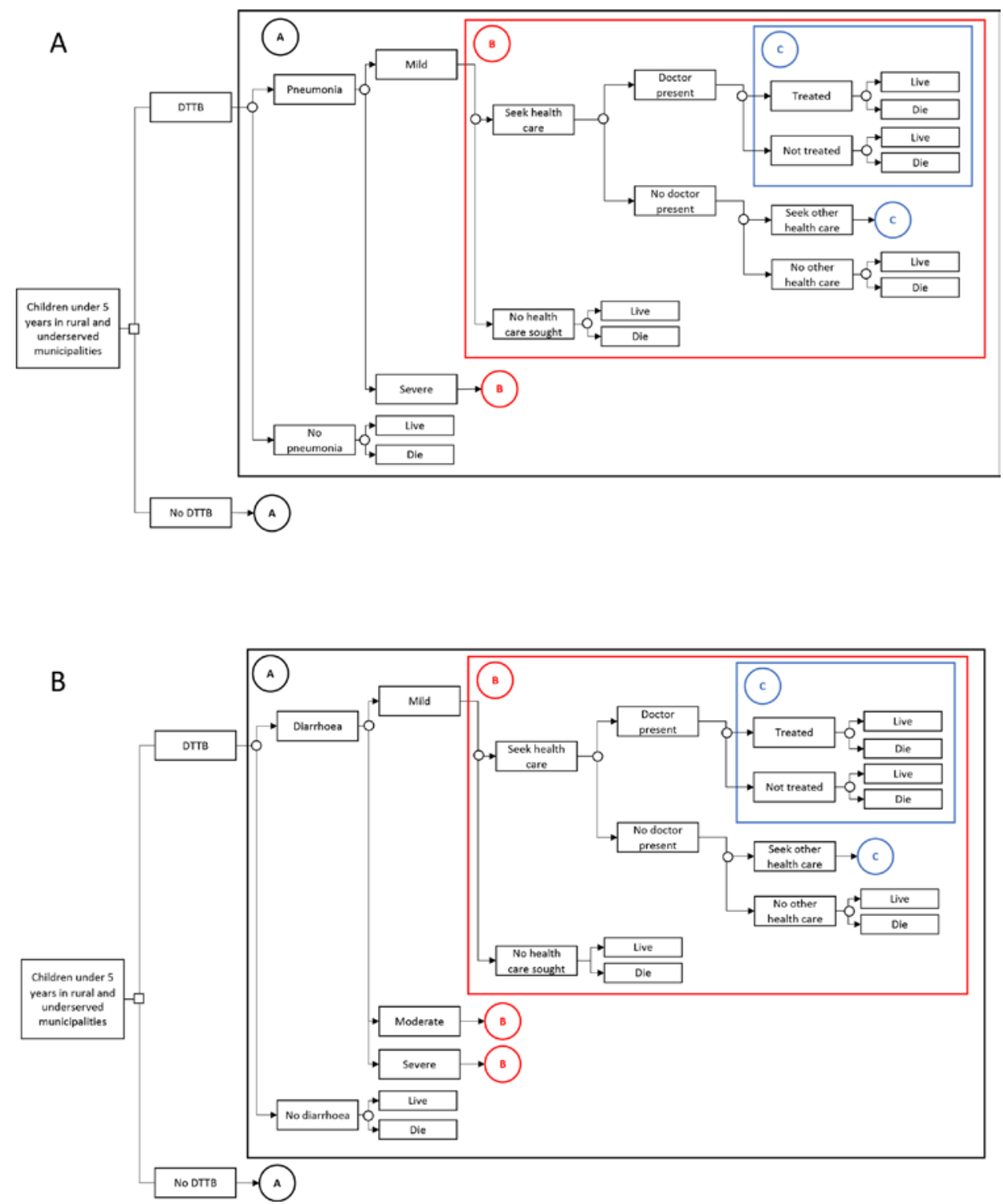

Figure 1 Diarrhoea (A) and pneumonia (B) decision tree models. Squares are decision nodes and circles are chance nodes. Each arrow represents a transition and is associated with a probability. Branches have been grouped, truncated and labelled appropriately for simplicity. The diarrhoea and pneumonia decisions tree models are similar in structure except in the classification of diseases; for pneumonia, mild and severe disease are modelled, while for diarrhoea, mild, moderate and severe diarrhoea are considered. DTTB, Doctor to the Barrios.

based on expert opinion, is assumed to be higher in the DTTB scenario than the without DTTB scenario. Without DTTB, rural municipalities hire MHOs and RHPs through standard procedures, which is often unsuccessful because remuneration for locally recruited physicians is relatively low.

We did not include all stages of disease progression in the decision trees; instead, we focused on care-seeking behaviour, access to care and clinical treatment outcomes (ie, mortality). We modelled mild, moderate and severe diarrhoea, but due to data limitations, we were only able to model pneumonia as either mild or severe. We did not explicitly model comorbidities, though we assumed that some children in the same municipality may, concurrently or successively, experience pneumonia and diarrhoea episodes in 1 year, as documented in the literature. ${ }^{37} 38$ The model was reviewed by officials in charge of HRH deployment programmes and health technology assessments at the DoH. Both models were created, and all analyses were conducted, in Microsoft Excel (Microsoft Corp, Redmond, Washington, USA).

The two sets of analyses (described previously) we conducted use different population numbers. For the set of analyses that looks at two specific provinces in the Philippines (Aklan and Nueva Ecija), we multiplied the average fraction of the population under 5 years $(9.95 \%$ and $9.91 \%$, respectively) with the average lowincome population (23281 and 24469 , respectively) at the municipal level (online supplementary file 1). For the analysis that looks at a representative municipality in the 
Philippines, the model starts with a cohort of 1904 children aged 3 years (in the base case) who are susceptible to pneumonia and diarrhoea. This cohort size was estimated by multiplying the average population size in lowincome and rural municipalities (15 641) by the average fraction of the population under 5 years $(12.17 \%)$ in the poorest regions in the Philippines (online supplementary file 1)..$^{39} 40$

Across all analyses, we assumed the average age of the population to be 3 years with an undiscounted life expectancy of 69 years; we vary the life expectancy assumption by \pm 3.45 years in sensitivity analysis. During the course of a year, a proportion of the population experiences diarrhoea and pneumonia based on annual incidence rates, and they progress through the decision tree based on the intervention, epidemiologic variables and transition probabilities and face lifetime outcomes following their disease and intervention.

\section{Data and sources}

Transition probabilities

We estimated annual transition probabilities based on medical and public health literature, as well as expert opinion (table 2). Several literature searches were conducted from June to September 2018 using MEDLINE via PubMed. Epidemiological parameters were taken from the Global Burden of Disease Study (GBD), the Philippines Field Health Services Information System (FHSIS) and studies that have classified diarrhoea and pneumonia cases by severity. ${ }^{22} 234142$ Province-specific pneumonia and diarrhoea incidence rates were estimated using FHSIS incidence rate ratios that we used to weigh the GBD incidence rates for pneumonia and diarrhoea (see online supplementary file 1). Treatment effectiveness for diarrhoea and pneumonia was taken from a prospective analysis, systematic review and previous modelling studies, and we assume $100 \%$ compliance with treatment. ${ }^{43-46}$

Treatment-related probabilities were estimated using data from a convenience sample of provinces in the Philippines (Aklan and Nueva Ecija). We also gathered expert opinion through interviews with DoH staff, provincial health officials and various DTTBs working as MHOs and RHPs conducted from June to October 2018 (online supplementary file 1). MHOs are the chief health officers of municipalities responsible for formulating and implementing medical and public health programs; RHPs provide preventive and curative services and oversee health personnel assigned in a RHU. ${ }^{47}$ While MHOs and RHPs are given the same salary grade, MHOs are higherin rank than RHPs.

The annual costs of DTTB were collected from the DoH, which include salaries and benefits given to DTTB physicians and costs associated with administering the deployment programme. Annual costs for physicians hired without DTTB were taken from the Department of Budget and Management compensation guide. ${ }^{48}$ We assumed that RHUs under with and without DTTB scenarios have equal numbers of allied healthcare staff, whose costs cancel out at the end and were therefore not valued. Similarly, we excluded municipal-level costs for recruiting MHOs and RHPs under the assumption that both DTTB and non-DTTB municipalities bear similar human resources costs.

Healthcare costs borne by payers and patients were estimated based on various published and unpublished studies from the Philippines. ${ }^{49-52}$ These costs include healthcare service costs (eg, physician and facility fees), drug costs and hospitalisations for severe disease. For the societal perspective, we calculated caregiver costs using the average daily income of workers in the Philippines weighted by the average length of stay of each disease and by disease severity. ${ }^{53}$ Other costs that are listed in the impact inventory were valued using different methodologies recommended by the 2nd Panel (online supplementary file 1$).{ }^{35}$

All costs are in 2017 Philippine pesos (50.40 Philippine pesos $(\mathrm{PHP})=\mathrm{US} \$ 1)$; historical costs were inflated using general consumer price indices from the World Bank. ${ }^{54}$ Lifetime production and consumption are discounted, but healthcare costs were not discounted because we only considered a 1 year implementation of DTTB.

\section{Utilities and health outcomes}

The decision tree model looks at two outcomes for diarrhoea and pneumonia, namely dead or alive. Death was assigned a utility of 0 , and living was assigned 1 (this value was varied from 0.9 to 1 in the sensitivity analyses). The exclusion of various intermediary morbidity states associated with diarrhoea and pneumonia in the model will likely underestimate the effectiveness of prompt and effective treatment for both with and without DTTB scenarios.

Two measures of effectiveness were estimated, namely QALYs gained and lives saved. Each life year lost from premature death due to diarrhoea, pneumonia or other causes was represented by one lost QALY in the base case. Lifetime discounted QALYs gained were calculated by multiplying the number of surviving children in the cohort by the discounted life expectancy of 28.73 years.

\section{Analysis}

\section{Cost-effectiveness}

We added the results of the two decision trees for pneumonia and diarrhoea to derive the total costs and effectiveness of the scenarios with and without DTTB. The physician deployment costs were added only after the total costs of the diarrhoea and pneumonia decision trees were calculated since these costs are shared between these two diseases.

The summary metric of cost-effectiveness analyses is the incremental cost-effectiveness ratio (ICER), defined as the cost per unit of health outcome gained. The ICER is calculated by dividing the incremental net costs by the incremental net benefits of one alternative versus the other. An intervention is typically considered costeffective if its ICER meets or is below a decision-maker's 
Table 2 Values for model variables*

\begin{tabular}{|c|c|c|c|c|}
\hline Variable & Base & Range & Distribution & Reference \\
\hline \multicolumn{5}{|l|}{ Population } \\
\hline $\begin{array}{l}\text { Population of children under } 5 \text { years in } \\
\text { representative rural municipality }\end{array}$ & 1904 & $280-6883$ & Normal & $t^{39}$ \\
\hline Population of children under 5 years in Aklan $\ddagger$ & 2318 & NA & NA & $t^{39} 40$ \\
\hline $\begin{array}{l}\text { Population of children under } 5 \text { years in Nueva } \\
\text { Ecijał }\end{array}$ & 2424 & NA & NA & $t^{39} 40$ \\
\hline Undiscounted life expectancy at 3 years & 69 & $65.55-72.45^{\star}$ & Normal & 58 \\
\hline \multicolumn{5}{|l|}{ Epidemiology } \\
\hline \multicolumn{5}{|l|}{ Pneumonia } \\
\hline $\begin{array}{l}\text { Probability of getting pneumonia in } \\
\text { representative rural municipality }\end{array}$ & 0.1028 & $0.0838-0.1233$ & Beta & 23 \\
\hline Probability of getting pneumonia in Aklan $\ddagger$ & 0.1301 & NA & NA & $t^{22} 2359$ \\
\hline $\begin{array}{l}\text { Probability of getting pneumonia in Nueva } \\
\text { Ecijał }\end{array}$ & 0.0502 & NA & NA & $\dagger^{22} 2359$ \\
\hline Proportion of cases that are severe & 0.10 & $0.05-0.15^{*}$ & Beta & 41 \\
\hline \multicolumn{5}{|l|}{ Diarrhoea } \\
\hline $\begin{array}{l}\text { Probability of getting diarrhoea in } \\
\text { representative rural municipality }\end{array}$ & 0.7379 & $0.6835-0.7928$ & Beta & 23 \\
\hline Probability of getting diarrhoea in Aklanł & 0.5863 & NA & NA & $t^{22} 2359$ \\
\hline Probability of getting diarrhoea in Nueva Ecijał & 0.4872 & NA & NA & $\dagger^{22} 2359$ \\
\hline Proportion of cases that are moderate & 0.347 & $0.10-0.4995^{\star}$ & Beta & 42 \\
\hline Proportion of cases that are severe & 0.5 & $0.05-0.10^{*}$ & Beta & 42 \\
\hline \multicolumn{5}{|l|}{ Annual transition probabilities } \\
\hline \multicolumn{5}{|l|}{ Pneumonia } \\
\hline $\begin{array}{l}\text { Probability of dying at age three for causes } \\
\text { other than pneumonia }\end{array}$ & 0.004 & $0.0038-0.0041$ & Beta & $t^{60}$ \\
\hline $\begin{array}{l}\text { Probability of seeking treatment given mild } \\
\text { disease }\end{array}$ & 0.89 & $0.50-1^{*}$ & Beta & 61 \\
\hline $\begin{array}{l}\text { Probability of dying with treatment of mild } \\
\text { disease }\end{array}$ & 0.035 & $0.0263-0.0438^{*}$ & Beta & 4344 \\
\hline $\begin{array}{l}\text { Probability of dying without treatment of mild } \\
\text { disease }\end{array}$ & 0.05 & $0.02-0.065^{\star}$ & Beta & 44 \\
\hline $\begin{array}{l}\text { Probability of seeking treatment given severe } \\
\text { disease }\end{array}$ & 0.91 & $0.50-1^{*}$ & Beta & 61 \\
\hline $\begin{array}{l}\text { Probability of dying without treatment of } \\
\text { severe disease }\end{array}$ & 0.21 & $0.05-0.25^{*}$ & Beta & 44 \\
\hline $\begin{array}{l}\text { Probability of dying with treatment of severe } \\
\text { disease }\end{array}$ & 0.1477 & $0.110-0.184^{*}$ & Beta & 4344 \\
\hline \multicolumn{5}{|l|}{ Diarrhoea } \\
\hline $\begin{array}{l}\text { Probability of dying at age } 3 \text { for causes other } \\
\text { than diarrhoea }\end{array}$ & 0.0046 & $0.0045-0.0047$ & Beta & $\dagger^{60}$ \\
\hline $\begin{array}{l}\text { Probability of seeking treatment given mild } \\
\text { disease }\end{array}$ & 0.4175 & $0.362-0.447$ & Beta & $t^{62}$ \\
\hline $\begin{array}{l}\text { Probability of dying given no treatment of mild } \\
\text { disease }\end{array}$ & 0.0018 & $0.0012-0.0027$ & Beta & 46 \\
\hline $\begin{array}{l}\text { Probability of dying with treatment of mild } \\
\text { disease }\end{array}$ & 0.0012 & $0.0009-0.0014^{*}$ & Beta & 4546 \\
\hline $\begin{array}{l}\text { Probability of seeking treatment given } \\
\text { moderate disease }\end{array}$ & 0.4175 & $0.362-0.447$ & Beta & $t^{62}$ \\
\hline
\end{tabular}


Table 2 Continued

\begin{tabular}{|c|c|c|c|c|}
\hline Variable & Base & Range & Distribution & Reference \\
\hline $\begin{array}{l}\text { Probability of dying given no treatment of } \\
\text { moderate disease }\end{array}$ & 0.0018 & $0.0012-0.0027$ & Beta & 46 \\
\hline $\begin{array}{l}\text { Probability of dying with treatment of mild } \\
\text { disease }\end{array}$ & 0.0012 & $0.0009-0.0014^{*}$ & Beta & 4546 \\
\hline $\begin{array}{l}\text { Probability of seeking treatment given severe } \\
\text { disease }\end{array}$ & 0.4175 & $0.362-0.447$ & Beta & $t^{62}$ \\
\hline $\begin{array}{l}\text { Probability of dying given no treatment of } \\
\text { severe disease }\end{array}$ & 0.0058 & $0.0039-0.0087$ & Beta & 46 \\
\hline $\begin{array}{l}\text { Probability of dying given treatment of severe } \\
\text { disease }\end{array}$ & 0.0014 & $0.001-0.0022$ & Beta & 4546 \\
\hline \multicolumn{5}{|l|}{ Treatment } \\
\hline $\begin{array}{l}\text { Probability that doctor is at the RHU with } \\
\text { DTTB }\end{array}$ & 0.9 & $0.8-1$ & Beta & Expert opinion \\
\hline $\begin{array}{l}\text { Probability that doctor is at the RHU without } \\
\text { DTTB§ }\end{array}$ & 0.15 & $0.075-0.225^{\star}$ & Beta & Expert opinion \\
\hline $\begin{array}{l}\text { Probability that patient is treated when doctor } \\
\text { is present }\end{array}$ & 0.75 & $0.50-1$ & Beta & $\begin{array}{l}\text { Expert opinion; } \\
\text { FHSIS }\end{array}$ \\
\hline $\begin{array}{l}\text { Probability that patient has other source of } \\
\text { care when doctor is not present } \emptyset\end{array}$ & 0.8 & $0.7-1^{*}$ & Beta & $\begin{array}{l}\text { Expert opinion; } \\
\text { FHSIS }\end{array}$ \\
\hline $\begin{array}{l}\text { Probability that patient is treated by other } \\
\text { source of care when doctor is not present }\end{array}$ & 0.75 & $0.50-1$ & Beta & $\begin{array}{l}\text { Assumed by } \\
\text { authors }\end{array}$ \\
\hline
\end{tabular}

Costs (in 2017 PHP) ${ }^{\star \star}$

\section{Pneumonia}

$\begin{array}{lcccc}\begin{array}{l}\text { Societal cost of treating severe pneumonia } \\ \text { episode }\end{array} & 48721 & 33395-64300 & \text { Gamma } & \dagger^{49-51} \\ \begin{array}{l}\text { Healthcare cost of treating severe pneumonia } \\ \text { episode }\end{array} & 47101 & 32577-61626 & \text { Gamma } & \dagger^{49-51} \\ \begin{array}{l}\text { Societal cost of treating mild pneumonia } \\ \text { episode }\end{array} & 6765 & 4694-7457 & \text { Gamma } & \dagger^{495062} \\ \begin{array}{l}\text { Healthcare cost of treating mild pneumonia } \\ \text { episode }\end{array} & 5485 & 4377-6582 & \text { Gamma } & \dagger^{495062}\end{array}$

Diarrhoea

\begin{tabular}{lllll}
$\begin{array}{l}\text { Societal cost of treating a mild diarrhoea } \\
\text { episode }\end{array}$ & 6765 & $5343-8222$ & Gamma & $t^{495162}$ \\
$\begin{array}{l}\text { Healthcare cost of treating a mild diarrhoea } \\
\text { episode }\end{array}$ & 6457 & $5165-7748$ & Gamma & $t^{495162}$ \\
$\begin{array}{l}\text { Societal cost of treating a moderate diarrhoea } \\
\text { episode }\end{array}$ & 11960 & $6629-17363$ & Gamma & $t^{4962}$ \\
$\begin{array}{l}\text { Healthcare cost of treating a moderate } \\
\text { diarrhoea episode }\end{array}$ & 11406 & $6323-16488$ & Gamma & $t^{4962}$ \\
$\begin{array}{l}\text { Societal cost of treating a severe diarrhoea } \\
\text { episode }\end{array}$ & 27575 & $19949-35617$ & Gamma & $t^{496263}$ \\
$\begin{array}{l}\text { Healthcare cost of treating a severe diarrhoea } \\
\text { episode }\end{array}$ & 25709 & $19234-32183$ & Gamma & $t^{496263}$ \\
$\begin{array}{l}\text { Other costs (discounted) } \\
\text { Lifetime consumption (in thousands) }\end{array}$ & 1697 & $1079-2817$ & Gamma & 64 \\
\hline $\begin{array}{l}\text { Lifetime productivity (in thousands) } \\
\text { Human resources (in thousands) }\end{array}$ & 2235 & $1406-3830$ & Gamma & 64 \\
\hline \begin{tabular}{l} 
Annual cost of deploying a DTTB physician \\
\hline
\end{tabular} & 1721 & $1500-2500$ & Gamma & DoH data \\
\hline
\end{tabular}




\begin{tabular}{|c|c|c|c|c|}
\hline Variable & Base & Range & Distribution & Reference \\
\hline $\begin{array}{l}\text { Annual cost of } \mathrm{MHO} \text { or RHP hired locally by } \\
\text { municipality }\end{array}$ & 926 & 880-976 & Gamma & DBM data \\
\hline \multicolumn{5}{|l|}{ Utilities } \\
\hline Alive & 1 & $0.9-1$ & Beta & $\begin{array}{l}\text { Assumed by } \\
\text { authors }\end{array}$ \\
\hline Discount rate & 0.03 & $0.02-0.08$ & NA & $\begin{array}{l}\text { Assumed by } \\
\text { authors }\end{array}$ \\
\hline
\end{tabular}

*Value assumed or set by authors.

†Base value and range calculated by authors based on the references cited.

$\ddagger$ No ranges and distributions are specified because only base case analyses were conducted using these data.

§Municipalities who do not participate in DTTB may still successfully hire a full-time physician to work as a RHP or MHO, or occasionally receive temporary physicians deployed by the provincial government or by a non-governmental organisation.

IIn many rural and underserved municipalities, RHUs are the only source of care, though some communities have privately practicing physicians or district hospitals nearby.

${ }^{* \star}$ Details behind cost calculations are found in the online supplementary file 1.

DBM, Department of Budget and Management; DoH, Department of Health; DTTB, Doctors to the Barrios; FHSIS, Field Health Services Information System; MHO, municipal health officer; NA, not applicable; PHP, Philippine pesos; RHP, rural health physician; RHU, rural health unit.

willingness-to-pay (WTP) threshold. In this study, we adopted the WHO-recommended WTP threshold, which is $100 \%$ of a country's per capita gross domestic product (GDP). In 2017, the GDP per capita of the Philippines was PHP $150654 .^{55}$

We report two sets of base case results; one set pertains to ICERs for Aklan and Nueva Ecija that uses selected province-specific inputs such as population size and disease incidence. Another set of ICERs is for the representative rural municipality that DTTBs are deployed to.

Sensitivity analyses

To address parameter uncertainty, we conducted one-way and probabilistic sensitivity analyses (PSA) for the representative rural municipality. Where data were available, low and high values were based on ranges in the literature; for parameters estimated through expert opinion, the authors determined reasonable bounds. For the PSA,
10000 Monte Carlo simulations were conducted using distributions of the variables (table 2). We generated costeffectiveness acceptability curves using the simulation results to plot the probability that each scenario is costeffective over a range of WTP thresholds.

\section{RESULTS}

Tables 3 and 4 summarise the base case costs, effectiveness and cost-effectiveness of the scenarios for the two sets of analyses. Compared with a no DTTB scenario, DTTB has an ICER of PHP 13042 per QALY gained in Aklan and PHP 47077 per QALY gained in Nueva Ecija using a societal perspective; these ICERs are respectively $9 \%$ and $31 \%$ of the WHO-recommended WTP threshold for the Philippines. ICERs for Aklan and Nueva Ecija are both

Table 3 Base case results for Aklan and Nueva Ecija*

\begin{tabular}{llllll}
\hline & Aklan & & & Nueva Ecija \\
\cline { 2 - 2 } Cost-effectiveness of DTTB & $\begin{array}{l}\text { Societal } \\
\text { perspective }\end{array}$ & $\begin{array}{l}\text { Healthcare } \\
\text { perspective }\end{array}$ & & $\begin{array}{l}\text { Societal } \\
\text { perspective }\end{array}$ & $\begin{array}{l}\text { Healthcare } \\
\text { perspective }\end{array}$ \\
\hline Incremental lives saved & 1.95 & 1.95 & 56.11 & 0.80 & 0.80 \\
Incremental QALYs gained & 56.11 & 731853 & 2673611 & 23.13 & 23.13 \\
Incremental costs & 374743 & 1369014 & 1352661 & 2336538 \\
Cost per life saved (in PHP) & 13042 & 47646 & 47077 & 2902548 \\
Cost per QALY gainedt(in PHP) & & & & 101018 \\
\hline
\end{tabular}

${ }^{*}$ All costs are in 2017 PHP and have been discounted to present time.

TQALYs are discounted to the present value.

DTTB, Doctors to the Barrios;PHP, Philippine pesos; QALY, quality-adjusted life year. 
Table 4 Base case results for representative rural municipality

\begin{tabular}{|c|c|c|c|c|}
\hline \multirow[b]{2}{*}{ Outcome } & \multicolumn{2}{|c|}{ Societal perspective } & \multicolumn{2}{|c|}{ Healthcare perspective } \\
\hline & With DTTB & Without DTTB & With DTTB & Without DTTB \\
\hline Lives saved & 3765 & 3763 & 3765 & 3763 \\
\hline Cost (in thousands PHP) & -2018691 & -2019692 & 6144 & 3499 \\
\hline Cost-effectiveness of DTTB & \multicolumn{2}{|c|}{ Societal perspective } & \multicolumn{2}{|c|}{ Healthcare perspective } \\
\hline Cost per QALY gained† (in PHP) & \multicolumn{2}{|l|}{27192} & \multicolumn{2}{|l|}{71839} \\
\hline
\end{tabular}

*All costs are in 2017 PHP and have been discounted to present value. Negative costs denote that the programme is cost saving. TQALYs are discounted to the present time.

DTTB, Doctors to the Barrios;PHP, Philippine pesos; QALY, quality-adjusted life year.

lower than the WHO-recommended WTP threshold form a healthcare perspective (32\% and $67 \%$, respectively).

Modelling a representative rural municipality provides additional insight on the factors that make DTTB a costeffective intervention for increasing access to pneumonia and diarrhoea treatment for children under 5 years (table 4). Having one DTTB doctor over the course of a year is expected to save about two lives and gain 89 discounted QALYs. From a societal perspective, DTTB has an ICER of PHP 27192 per QALY gained, which is only $18 \%$ of the WHO-recommended WTP threshold. From a healthcare perspective, the ICER of DTTB is PHP 71839 per QALY gained, which is $48 \%$ of the WHOrecommended WTP threshold.

Figure 2 shows the partial results of the one-way sensitivity analysis from a healthcare perspective. The extreme values of two parameters-(1) the probability that a patient is treated by another source of care and
(2) the probability that a patient is treated when doctor is present-cause the scenario with DTTB to be dominated by the scenario without DTTB. At these extremes, the overall probability a child is treated is higher in the without DTTB than with DTTB. The extreme values of four other parameters (ie, probability of dying without treatment of severe pneumonia, population size, probability of dying after treatment of severe pneumonia and discount rate) shift the ICER enough to surpass the WHO-recommended WTP threshold.

Across 10000 simulations, DTTB on average has ICERs of PHP 21362 per QALY gained and PHP 610615 per life saved from a societal perspective; about $17 \%$ of simulations estimated that DTTB is cost saving (ie, negative net costs and positive net benefits). From a healthcare perspective, the average ICERs of DTTB are about PHP 75 568 per QALY gained (50\% of the WHO-recommended WTP threshold) and PHP 2.2 million per life saved.

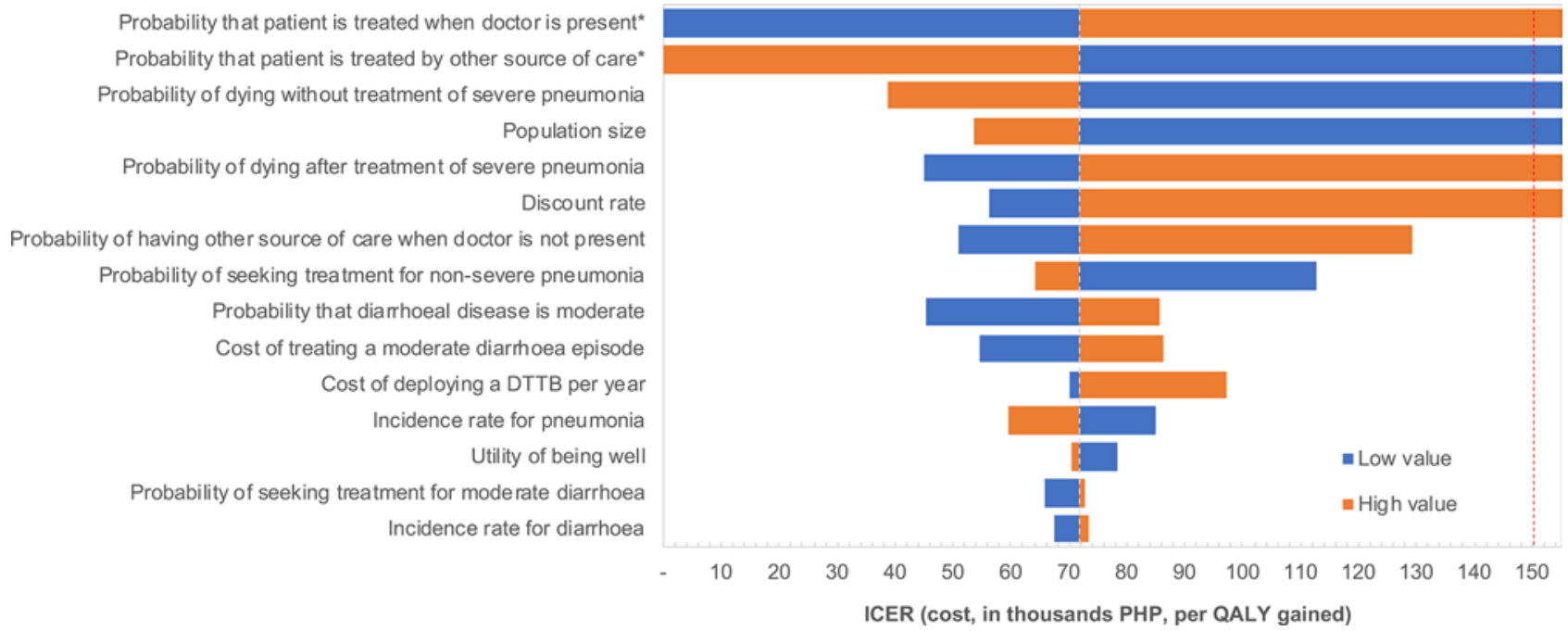

Figure 2 Tornado diagram showing results of one-way sensitivity analysis from a healthcare perspective. A tornado diagram shows the full ICER range when a parameter value in the model is varied from its lowest to highest bounds while keeping the other parameter values constant. The grey vertical dashed line represents the ICER in the base case for the healthcare perspective, and the red vertical dashed line represents the WHO-recommended WTP threshold. Asterisks $\left({ }^{*}\right)$ denote that extreme values of the parameter cause the with DTTB scenario to be dominated by the without DTTB scenario. Only the top 15 most influential parameters are included in this figure. DTTB, Doctor to the Barrios; ICER, incremental cost-effectiveness ratio; PHP, Philippine pesos; QALY, quality-adjusted life year; WTP, willingness-to-pay. 
A

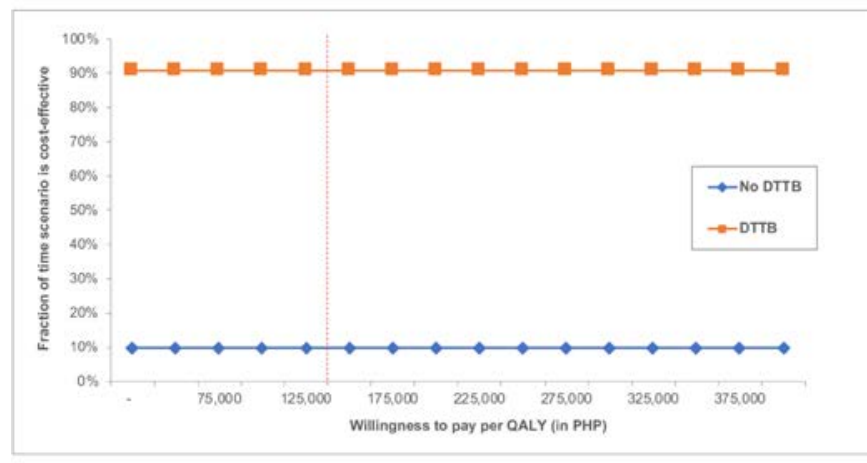

B

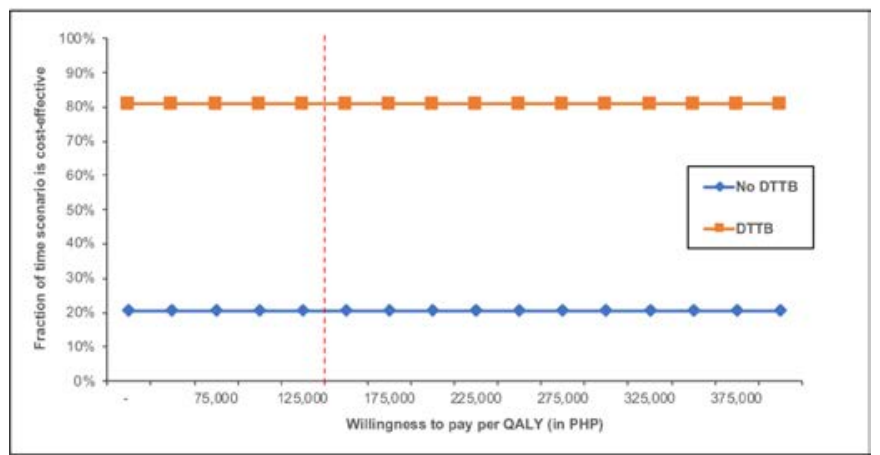

Figure 3 Cost-effectiveness acceptability curves for the (A) societal and (B) healthcare perspectives. These curves plot the probability that each alternative is cost-effective (ie, has a higher net monetary value) over a range of WTP thresholds. The red vertical dashed line represents the WHOrecommended WTP threshold. DTTB, Doctor to the Barrios; PHP, Philippine pesos; QALY, quality-adjusted life year; WTP, willingness-to-pay.

Figure 3 shows the cost-effectiveness acceptability curves for the societal and healthcare perspectives. Across different WTP values, the scenario with DTTB is much more likely to be the optimal choice when compared with without DTTB from both the societal and healthcare perspectives.

\section{DISCUSSION}

This study suggests that DTTB, a physician deployment programme in the Philippines, can be a cost-effective intervention; however, its value varies by setting the characteristics of the municipality in which it is implemented. The results support the continued use and expansion of DTTB in areas with little to no sources of medical care to prevent pneumonia-related and diarrhoea-related mortality in children under 5 years. The sensitivity analysis also highlights the importance of the availability of the deployed DTTB physician to treat patients; if the physicians are largely unavailable to provide medical care (for reasons such as being pulled into municipal events or meetings, or leaving the municipality to attend trainings or conferences), then the economic efficiency of DTTB decreases.
There are several limitations associated with this study that are worth noting. First, we combined different sources of data to estimate costs and health benefits, and some secondary sources were not specific to the Philippine context. Thus, there is considerable parameter uncertainty that we tried to mitigate through the use of wide parameter ranges in sensitivity analyses. The parameter estimates derived through expert opinion may also be biased since we primarily interviewed DTTB physicians who view their work positively. We also did not include as a parameter the costs associated with death. (We detail other data limitations and assumptions in the online supplementary file.) Future research should focus on empirically estimating the value of parameters provided by experts, particularly those that had a significant impact on the ICER (see figure 2). Second, we have likely underestimated the health benefits of DTTB by considering a narrow set of health outcomes in children. This is a significant limitation of the study, which can be addressed in future cost-effectiveness analyses where other health conditions (eg, prevention, diagnosis and treatment of cardiovascular diseases) can be included in the model. Future studies can also look at the health-related quality of life of intermediate health states between alive and dead. Third, the convenience sample of municipalities on which several parameter estimates were based may not be representative of all rural and underserved municipalities in the Philippines.

Fourth, the decision tree model, though intended to be a simplification of actual healthcare-seeking processes, may exclude certain events that affect the estimation of DTTB's health benefits. For example, timing of treatment and availability of appropriate drugs are likely to impact treatment effectiveness, but we made simplifying assumptions around these factors. We also did not differentiate pneumonia and diarrhoea cases by aetiologic agent, and we did not model how treatment of pneumonia and diarrhoea in children may prevent others from contracting the disease. We did, however, try to address these limitations by ensuring that DoH staff and other experts were consulted in the development of the decision models. Finally, the generalisability of this study is limited; the CEA only generates average estimates of cost-effectiveness based on the current design and specifications of the DTTB programme. Thus, any changes to the DTTB programme may alter the estimation of costs, benefits and the ICER. For example, we assumed that DTTB physicians are deployed to municipalities with limited to no access to other healthcare providers (so-called 'doctorless municipalities'); if DTTB physicians are deployed to areas with more healthcare providers that patients can access, the impact of DTTB may change.

This study contributes to the limited literature on the cost-effectiveness of various strategies to improve HRH density in rural and underserved areas. A study by Lagarde and colleagues found that offering a study leave to rural nurses and recruiting nurses from rural areas were the most cost-effective strategies compared with the status 
quo with an ICER of South African Rand 200 215-241 073 per nurse-year (roughly 27 108-32640 per nurse-year in 2017 US\$). ${ }^{56}$ The main limitation of this study is that the effectiveness of the strategies was estimated in nurse-years and not health outcomes; thus, the findings of the study cannot be compared with other health interventions.

Another study by Keuffell et al explored the costeffectiveness of 15 separate non-wage financial incentive packages (eg, transportation allowances, housing incentives) for new physicians in Lao People's Democratic Republic (Lao PDR) ${ }^{57}$ Effectiveness was calculated using a WHO analysis that estimates the potential (non-linear) reductions in infant mortality, under 5 years mortality and maternal mortality from increases in physician density. This feature of the study was a major limitation as the WHO analysis is based on a cross-national sample; thus, the estimates of health impact may or may not be applicable to the Lao PDR context. ${ }^{11}$ Nonetheless, the authors found that a package consisting of housing and transportation allowance and career promotion opportunities was the most cost-effective option over a 5 year time horizon (compared with a no programme scenario) with an ICER of about US\$1454 per QALY gained (2012 US\$).

This study is the first CEA to evaluate an HRH deployment programme in the Philippines and has demonstrated that DTTB can be cost saving or cost-effective depending on the perspective used. The methods we employed can be used evaluate the cost-effectiveness of other HRH deployment programmes in the country (eg, midwife deployment to increase facility-based deliveries). However, empirical analyses are needed to understand the total health impact of deployment programmes which can inform future cost-effectiveness models using other simulation techniques such as state-transition models. Results from this study can be used by national and local government officials to inform HRH allocation decisions.

Acknowledgements The authors extend their gratitude to Dr Kenneth Ronquillo, Dr Beverly Ho, and several staff members of the Health Policy Development and Planning Bureau of the Philippines Department of Health for their support for this project. The authors also thank the various physicians working as Doctors to the Barrios who provided critical information for this study (full list of interviewees is found in the Supplemental File).

Contributors ALVA conceived and designed the study, collected and analysed the data, prepared the manuscript and is the guarantor of the study. KPST implemented the study and prepared the manuscript. DWH designed the study, analysed the data, prepared the manuscript and provided oversight throughout the study. All authors have approved the final submitted version.

Funding This study was supported by grants from the University of Michigan's International Institute and the Office of Global Public Health at the School of Public Health.

Competing interests None declared.

Patient consent for publication Not required.

Ethics approval This study did not involve patients and qualifies as an evaluation, which is exempt from ethical review.

Provenance and peer review Not commissioned; externally peer reviewed.

Data availability statement All data relevant to the study are included in the article or uploaded as supplementary information. All input parameters in the model are reported in the main text and supplementary materials.
Open access This is an open access article distributed in accordance with the Creative Commons Attribution Non Commercial (CC BY-NC 4.0) license, which permits others to distribute, remix, adapt, build upon this work non-commercially, and license their derivative works on different terms, provided the original work is properly cited, appropriate credit is given, any changes made indicated, and the use is non-commercial. See: http://creativecommons.org/licenses/by-nc/4.0/.

\section{ORCID iDs}

Anton L.V. Avanceña http://orcid.org/0000-0002-4903-870X

David W. Hutton http://orcid.org/0000-0001-9677-1632

\section{REFERENCES}

1 The World Bank. Rural population (\% of total population), 2017. Available: https://data.worldbank.org/indicator/SP.RUR.TOTL.ZS [Accessed 11 Jan 2018].

2 World Health Organization Regional Office for the Western Pacific. Human resources for health country profiles: Philippines. Geneva: World Health Organization, 2013.

3 Health Human Resource Development Bureau. National database of selected human resources for health, 2017. Available: http://www. ndhrhis.com/ [Accessed 24 Jan 2018].

4 Senate of the Philippines. Senate approves universal health care bill, 2018. Available: http://www.senate.gov.ph/press_release/2018/1010 prib3.asp [Accessed 15 Nov 2018].

5 Ranada P. Duterte signs universal health care law. Rappler, 2019. Available: https://www.rappler.com/nation/223942-duterte-signsuniversal-health-care-law [Accessed 2 Jun 2019].

6 Department of Health. About us, 2017. Available: http:// doctorstothebarrios.com/about/ [Accessed 11 Jan 2018].

7 Leonardia JA, Prytherch H, Ronquillo K, et al. Assessment of factors influencing retention in the Philippine national rural physician deployment program. BMC Health Serv Res 2012;12:411.

8 Starfield B, Shi L, Macinko J. Contribution of primary care to health systems and health. Milbank Q 2005;83:457-502.

9 World Health Organization. The world health report 2006: working together for health. Geneva: World Health Organization, 2006.

10 Shi L. The impact of primary care: a focused review. Scientifica 2012;2012:1-22.

11 Speybroeck N, Kinfu Y, MRD P. Reassessing the relationship between human resources for health, intervention coverage and health outcomes, 2006. Available: https://pdfs.semanticscholar.org/ fb21/eb31a783e802b2869f291ad29c80bf26ff04.pdf [Accessed 8 Apr 2018].

$12 \mathrm{Li} \mathrm{H}$, Liu K, Gu J, et al. The development and impact of primary health care in China from 1949 to 2015: a focused review. Int $J$ Health Plann Manage 2017;32:339-50.

13 Barry J. The relationship between the supply of primary care physicians and measures of breast health service use. J Womens Health 2017;26:511-9.

14 Pathman DE, Ricketts TC, Konrad TR. How adults' access to outpatient physician services relates to the local supply of primary care physicians in the rural Southeast. Health Serv Res 2006;41:79-102.

15 Chen L, Evans T, Anand S, et al. Human resources for health: overcoming the crisis. The Lancet 2004;364:1984-90.

16 Ananthakrishnan AN, Hoffmann RG, Saeian K. Higher physician density is associated with lower incidence of late-stage colorectal cancer. J Gen Intern Med 2010;25:1164-71.

17 Anand S, Bärnighausen T. Health workers and vaccination coverage in developing countries: an econometric analysis. The Lancet 2007;369:1277-85

$18 \mathrm{Hu}$ Y, Shen L, Guo J, et al. Public health workers and vaccination coverage in eastern China: a health economic analysis. Int $J$ Environ Res Public Health 2014;11:5555-66.

19 Anand S, Bärnighausen T. Human resources and health outcomes: cross-country econometric study. The Lancet 2004;364:1603-9.

20 Sakai R, Fink G, Kumamaru $\mathrm{H}$, et al. The impact of pediatrician supply on child health outcomes: longitudinal evidence from Japan. Health Serv Res 2016;51:530-49.

21 Department of Health. Leading causes of child mortality, 2014. Available: https://www.doh.gov.ph/Statistics/Leading-Causes-ofChild-Mortality [Accessed 3 Jul 2018].

22 Surveys, Monitoring and Evaluation Division. Field health services information system 2018 annual report, 2018. Available: https://www. doh.gov.ph/sites/default/files/publications/FHSIS_Annual_2018.pdf [Accessed 10 Oct 2019].

23 Institute of Health Metrics and Evaluation. GBD results tool. Glob. health data Exch, 2018. Available: http://ghdx.healthdata.org/gbdresults-tool [Accessed 19 Oct 2018]. 
24 Azmi S, Aljunid SM, Maimaiti N, et al. Assessing the burden of pneumonia using administrative data from Malaysia, Indonesia, and the Philippines. Int J Infect Dis 2016;49:87-93.

25 Zar HJ, Madhi SA, Aston SJ, et al. Pneumonia in low and middle income countries: progress and challenges. Thorax 2013;68:1052-6.

26 Elliott EJ. Acute gastroenteritis in children. BMJ 2007;334:35-40.

27 National Antibiotic Guidelines Committee. National antibiotic guidelines 2017. Quezon City, Philippines: Department of Health, 2017. http://icamr.doh.gov.ph/images/PDF/NAG_GastrointestinalInfections April-2017.pdf

28 Graves NS. Acute gastroenteritis. Prim Care 2013;40:727-41.

29 Das JK, Salam RA, Bhutta ZA. Global burden of childhood diarrhea and interventions. Curr Opin Infect Dis 2014;27:451-8.

30 Venkatesan MM, Van de Verg LL. Combination vaccines against diarrheal diseases. Hum Vaccines Immunother 2015;11:1434-48.

31 Nguyen TKP, Tran TH, Roberts CL, et al. Child pneumonia - focus on the Western Pacific Region. Paediatr Respir Rev 2017;21:102-10.

32 Root ED, Lucero M, Nohynek H, et al. Distance to health services affects local-level vaccine efficacy for pneumococcal conjugate vaccine (PCV) among rural Filipino children. Proc Natl Acad Sci U S A 2014;111:3520-5

33 Root ED, Lucero M, Nohynek H, et al. Distance to health services modifies the effect of an 11-valent pneumococcal vaccine on pneumonia risk among children less than 2 years of age in Bohol, Philippines. Int J Epidemiol 2017;46:706-16.

34 Dayrit ES. Rotavirus vaccination in the Philippines: growing pains, 2016. Available: https://www.sabin.org/sites/sabin.org/files/elvira dayrit.pdf [Accessed 10 Oct 2019].

35 Neumann PJ, Sanders GD, Russell LB, eds. Cost-effectiveness in health and medicine. 2nd edn. New York: Oxford University Press, 2017.

36 Husereau D, Drummond M, Petrou S, et al. Consolidated health economic evaluation reporting standards (cheers) statement. BMJ 2013;346

37 Leung DT, Das SK, Malek MA, et al. Concurrent pneumonia in children under 5 years of age presenting to a diarrheal hospital in Dhaka, Bangladesh. Am J Trop Med Hyg 2015;93:831-5.

38 Chisti MJ, Salam MA, Ashraf $\mathrm{H}$, et al. Clinical signs of radiologic pneumonia in under-five hypokalemic diarrheal children admitted to an urban hospital in Bangladesh. PLoS One 2013;8:e71911.

39 Philippine Statistics Authority. Highlights of the Philippine population 2015 census of population, 2016. Available: https://psa.gov.ph/ content/highlights-philippine-population-2015-census-population [Accessed 10 Dec 2018].

40 Philippine Statistics Authority. Philippine population surpassed the 100 million mark (results from the 2015 census of population), 2017. Available: https://psa.gov.ph/content/philippine-populationsurpassed-100-million-mark-results-2015-census-population [Accessed 11 Dec 2018].

41 Lim Y-W, Steinhoff M, Girosi F, et al. Reducing the global burden of acute lower respiratory infections in children: the contribution of new diagnostics. Nature 2006;444:9-18.

42 Lamberti LM, Fischer Walker CL, Black RE. Systematic review of diarrhea duration and severity in children and adults in low- and middle-income countries. BMC Public Health 2012;12:276.

43 Theodoratou E, Al-Jilaihawi S, Woodward F, et al. The effect of case management on childhood pneumonia mortality in developing countries. Int J Epidemiol 2010;39:i155-71.

44 Quiambao BP, Ruutu PJ, Ladesma EA, et al. Pneumonia among young infants in rural Southeast Asia (Bohol Island, Philippines). Trop Med Int Health 2009;14:1457-66.

45 Munos MK, Walker CLF, Black RE. The effect of oral rehydration solution and recommended home fluids on diarrhoea mortality. Int $J$ Epidemiol 2010;39:i75-87.
46 Robberstad B, Strand T, Black RE, et al. Cost-Effectiveness of zinc as adjunct therapy for acute childhood diarrhoea in developing countries. Bull World Health Organ 2004;82:523-31.

47 Department of Budget and Management. Chapter 9: position classification and compensation scheme in local government units, 2012. Available: https://www.dbm.gov.ph/wp-content/uploads/2012/ 03/Manual-on-PCC-Chapter-9.pdf

48 Department of Budget and Management. Implementation of the third tranche compensation adjustment for civilian personnel in the National government, 2018. Available: https://www.dbm.gov.ph/ wp-content/uploads/lssuances/2018/National Budget Circular/NBCNo572.pdf [Accessed 11 Dec 2018].

49 Camiling-Alfonso R. Technical assistance for the costing of inpatient benefit package for adult and pediatric UTI, age and pneumonia. Manila: Department of Health, 2017.

50 PhilHealth. List of medical case rates, 2017. Available: https:// www.philhealth.gov.ph/circulars/2017/annexes/0019/AnnexAMedicalCaseRates.pdf [Accessed 1 Aug 2018]

51 Tumanan-Mendoza BA, Mendoza VL, Frias MVG, et al. Economic burden of community-acquired pneumonia among pediatric patients (aged 3 months to. Value Health Reg Issues 2017;12:115-22.

52 Ulep VGT, Dela Cruz NAO. Analysis of out-of-pocket expenditures in the Philippines. Philipp J Dev 2013;XL:93-123.

53 Department of Labor and Employment. Daily minimum wage rates, 2018. Available: http://www.nwpc.dole.gov.ph/ [Accessed 2 Nov 2018].

54 The World Bank. Consumer price index $(2010=100), 2018$ Available: https://data.worldbank.org/indicator/FP.CPI.TOTL?end= 2017\&locations $=P H \&$ start $=1960 \&$ view $=$ chart $[$ Accessed 1 Nov 2018].

55 World Bank. World development indicators, 2017. Available: http://databank.worldbank.org/data/reports.aspx?source=worlddevelopment-indicators\# [Accessed 22 Sep 2017].

56 Lagarde M, Blaauw D, Cairns J. Cost-Effectiveness analysis of human resources policy interventions to address the shortage of nurses in rural South Africa. Soc Sci Med 2012;75:801-6.

57 Keuffell E, Jaskiewicz W, Theppanya K, et al. Cost-Effectiveness of rural incentive packages for graduating medical students in Lao PDR. Int J Health Policy Manag 2016;6:383-94.

58 United Nations Population Division. World population prospects 2017, 2017. Available: https://population.un.org/wpp/DataQuery/ [Accessed 11 Dec 2018]

59 Philippine Statistics Authority. Updated population projections based on the results of 2015 POPCEN, 2019. Available: https://psa.gov.ph/ statistics/census/projected-population [Accessed 29 Oct 2019].

60 World Health Organization. Life tables by country: Philippines. World Health Organization, 2016. http://apps.who.int/gho/data/view.main. LT62150

61 Kosai H, Tamaki R, Saito M, et al. Incidence and risk factors of childhood pneumonia-like episodes in Biliran Island, Philippines--a community-based study. PLoS One 2015;10:e0125009.

62 Philippine Statistics Authority, ICF. Philippines national demographic and health survey 2017. Quezon City, Philippines, and Rockville, Maryland, USA: PSA and ICF, 2018. https://dhsprogram.com/pubs/ pdf/FR347/FR347.pdf

63 Tobe M, Stickley A, del Rosario RB, et al. Out-Of-Pocket medical expenses for inpatient care among beneficiaries of the National health insurance program in the Philippines. Health Policy Plan 2013;28:536-48

64 Philippine Statistics Authority. 2015 family income and expenditure survey (FIES). Quezon City, Philippines: Philippine Statistics Authority, 2015. https://psa.gov.ph/sites/default/files/FIES 2015 Final Report.pdf 